\title{
PENERAPAN TEKNIK ASEPTIK PADA ASUHAN KEPERAWATAN DI RUANG BEDAH RSUD KABUPATEN ENDE
}

\author{
Irwan Budiana ${ }^{1}$, Kornelia Fania Nggarang ${ }^{2}$ \\ ${ }^{1}$ Jurusan Keperawtan, Politeknik Kesehatan Kemenkes Kupang/ Indonesia \\ ${ }^{2}$ Jurusan Keperawtan, Politeknik Kesehatan Kemenkes Kupang/ Indonesia
}

\begin{abstract}
Abstrak
Masih tingginya kejadian infeksi nosokomial di Rumah Sakit menjadi salah satu penyebab pentingnya dilakukan penerapan teknik aseptik oleh tenaga kesehatan terlebih tenaga keparawatan sebagai upaya pencegahan dalam melakukan tindakan yang membawa resiko masuknya mikroorganisme ke dalam tubuh pasien. Ada dua (2) jenis teknik aseptik dalam praktek keperawatan yaitu aseptik medis dan aseptik bedah. Tujuan penelitian adalah untuk mengetahui penerapan teknik aseptik dalam perawatan pasien di Ruang Perawatan Bedah Rumah Sakit Umum Daerah Ende. Jenis penelitian deskriptif dengan design penelitian survey. Populasinya seluruh perawat Ruangan Bedah Rumah Sakit Umum Daerah Ende yang berjumlah 12 orang. Teknik pengambilan sampelnya sampling jenuh, sehingga jumlah sampelnya 12 orang. Hasil penelitian menunjukkan 9 orang $(75,0 \%)$ menerapkan teknik aseptik medis yang cukup dan 3 orang (25\%) menerapkan tehnik aseptik medis yang baik. Untuk tehnik aseptik bedah, 7 orang $(58,3 \%)$ menerapkan teknik aseptik bedah yang baik. Dapat disimpulkan bahwa untuk tehnik aseptik medis yang baik, masih sedikit perawat yang melakukan, sedangkan untuk tehnik aseptik bedah yang baik telah dilakukan oleh sebagian besar perawat. Disarankan agar perawat senantiasa meningkatkan keterampilan dan lebih memahami peranan dan fungsi dari seorang perawat, sehingga perawat mampu untuk memberikan pelayanan yang baik dan profesional dimulai dari penerapan tehnik aseptik dalam setiap tindakan keperawatan. Hal ini bertujuan agar pasien mendapatkan kenyamanan dan rasa aman yang secara tidak langsung berdampak pada cepatnya proses penyembuhan.
\end{abstract}

Kata Kunci : Teknik Aseptik, Perawatan, Pelayanan, Infeksi

\section{THE IMPLEMENTATION OF ASEPTIC TECHNIQUE IN NURSING CARE IN SURGICAL WARD OF ENDE GENERAL HOSPITAL}

The high incidence of nosocomial infection in hospital indicate the importance of implementation of aseptic technique by the health professionals especially nurses as the efforts to prevent microorganisms entering the patient's body. There are two types of aseptic techniques in nursing practice, namely medical aseptic and surgical aseptic. The purpose of this study was to determine the implementation of aseptic techniques in patient care in the Surgical Ward of Ende General Hospital. This is a descriptive study with survey research design. The population is all nurses in the Surgical Ward of Ende General Hospital, amounting to 12 people. The sampling technique is saturated sampling, so the number of samples is 12 people. The results showed only 3 nurses (25\%) applied good medical aseptic technique, while the other 9 nurses (75\%) applied adequate medical aseptic technique. For surgical aseptic technique, most of nurses have applied good technique (7 people/58.3\%). It is recommended that nurses always improve their skills and have a better understanding of the roles and functions of a nurse, so that nurses are able to provide good and professional service. It is started by implementing good medical and surgical aseptic technique.

Keywords: Aseptic Technique, Care, Nursing Care, Nosocomial Infection 


\section{PENDAHULUAN}

Rumah Sakit (RS) merupakan suatu unit yang sangat kompleks. Kompleksitas ini tidak hanya berkaitan dengan Rumah Sakit sebagai tempat pelayanan medis namun juga sebagai tempat yang paling mungkin menularkan infeksi (nosokomial) baik pada pasien, petugas kesehatan maupun masyarakat yang berkunjung. Rumah sakit (RS) merupakan sumber infeksi bagi petugas kesehatan, pasien dan juga pengunjung. Risiko infeksi di rumah sakit dikenal dengan istilah infeksi nosokomial merupakan masalah kesehatan global. Infeksi terkait pelayanan kesehatan atau Healthcare Associated Infection (HAIs) merupakan salah satu masalah global termasuk di Indonesia. World Health Organization (WHO) menunjukkan bahwa prevalensi kejadian HAIs pada pasien sebesar $7 \%$ di negara maju dan $10 \%$ di negara berkembang terjadi setiap tahunnya (WHO, 2016). Centre for Disease Control and Preventin $(C D C)$ Menyebutkan bahwa infeksi ini terus meningkat di berbagai negara (CDC, 2015). Kejadian infeksi nosokomial di sepuluh RS Indonesia tahun 2010 cukup tinggi yaitu 6-16\% dengan rata-rata 9,8\%. Infeksi nosokomial paling umum terjadi adalah infeksi luka operasi (ILO). Hasil penelitian terdahulu menunjukkan bahwa angka kejadian ILO pada RS di Indonesia bervariasi antara 2-18\% dari keseluruhan prosedur pembedahan (Jeyamohan, 2010). Untuk itu setiap petugas kesehatan baik dokter atau perawat dituntut untuk dapat melakukan tindakan aseptik dengan baik dan benar, sehingga tidak terjadi infeksi berkelanjutan terhadap pasien.

Teknik aseptik merupakan metode penjagaan yang digunakan dalam setiap tindakan yang membawa resiko masuknya mikroorganisme ke dalam tubuh pasien (Hinchliff, 1999). Ada dua (2) jenis teknik aseptik dalam praktek keperawatan yaitu aseptik medis dan aseptik bedah. Aseptik medis adalah teknik atau prosedur yang dilakukan untuk mengurangi jumlah mikroorganisme disuatu obyek, serta menurunkan kemungkinan penyebaran dari mikroorganisme tersebut. Aseptik medis dikenal juga sebagai teknik bersih seperti mencuci tangan, mengganti lien ditempat tidur dan menggunakan cangkir untuk obat. Sedangkan aseptik bedah atau teknik steril termasuk prosedur yang digunakan untuk membunuh mikroorganisme dari suatu daerah. Sterilisasi membunuh semua mikroorganisme dan spora (Rutala, 2003). Setelah suatu obyek menjadi tidak steril atau tidak bersih, obyek tersebut terkontaminasi. Pada aseptik medis suatu area atau objek dinyatakan terkontaminasi jika area atau obyek tersebut mengandung atau diduga mengandung pathogen. Misalnya bedpan yang sudah dipakai, lantai dan kassa yang basah merupakan contoh obyek yang terkontaminasi (Febriani, 2015).

Infeksi nasokomial merupakan salah satu akibat yang dapat timbul jika perawat tidak melakukan tindakan aseptik. Survei prevalensi yang dilakukan WHO di 55 Rumah Sakit dari 14 negara yang mewakili 4 Kawasan WHO (Eropa, Timur Tengah, Asia Tenggara dan Pasifik Barat) menunjukkan ratarata 8,7\% pasien Rumah Sakit mengalami infeksi nosokomial. Setiap saat, lebih dari 1,4 juta orang di seluruh dunia menderita komplikasi dari infeksi yang diperoleh di Rumah Sakit. Frekuensi tertinggi infeksi nosokomial dilaporkan dari Rumah Sakit di Kawasan Timur Tengah dan Asia Tenggara $(11,8 \%$ dan 10,0\% masing-masing), dengan prevalensi 7,7\% dan 9,0\% masing-masing di Kawasan Eropa dan Pasifik Barat (WHO, 2002). 
Penelitian lain menyebutkan bahwa infeksi nosokomial dilaporkan rata-rata sekitar 3,5\% (Jerman) menjadi 5\% (AS) dari seluruh pasien rawat inap, di perawatan Rumah Sakit tersier sekitar 10\% dan di ICU sekitar 15\%-20\% kasus (Kayser, 2005). Menurut Kasmad (2007), di negara-negara berkembang termasuk Indonesia, kejadian infeksi nosokomial jauh lebih tinggi jika di bandingkan dengan negara-negara lainnya, kejadian infeksi nosokomial sekitar 39\%-60\%. Sedangkan angka di daerah pada tahun 2016 dilaporakan angkanya mencapai 0,17\%, pada bulan Maret 0,15\%, bulan Mei $0,04 \%$ dan pada bulan Juni mengalami peningkatan menjadi 0,69\%. Berbagai faktor yang mempengaruhi terjadinya infeksi antara lain adalah kuman penyakit, sumber infeksi, perantara atau pembawa kuman, daya tahan tubuh, keadaan Rumah Sakit yang meliputi prosedur kerja, alat, hygiene, kebersihan, jumlah pasien, pemakaian antibiotik yang irasional dan konstruksi Rumah Sakit (Darmadi, 2008, dalam Verawati, 2015).

Kesehatan yang baik tergantung pada lingkungan yang aman. Praktisi atau teknisi yang memantau untuk mencegah penularan infeksi membantu melindungi klien dan pekerja keperawatan kesehatan dari penyakit. Klien dalam lingkungan keperawatan beresiko terkena infeksi karena daya tahan yang menurun terhadap mikroorganisme infeksius, meningkatnya pajanan terhadap jumlah dan jenis penyakit yang disebabkan oleh mikroorganisme dan prosedur invasif dalam fasilitas perawatan akut atau ambulatory. Klien dapat terpajan pada mikroorganisme baru atau berbeda, yang beberapa dari mikroorganisme tersebut dapat saja resisten terhadap banyak antibiotik, sehingga perawat dituntut untuk mempraktikan teknik pencegahan penyebaran mikroorganisme terhadap klien dengan menerapkan teknik aseptik. Berdasarkan pengamatan yang dilakukan peneliti di RSUD Kabupaten Ende, khususnya di ruang perawatan bedah, didapatkan bahwa beberapa pasien yang dirawat lebih dari seminggu mengeluhkan nyeri dan bengkak pada luka bekas operasi, suhu badan meninggi dan keterbatasan dalam menggerakan anggota tubuh. Hal ini diindikasikan bahwa para pasien tersebut terkena infeksi. Dampak dari infeksi nasokomial yakni dapat menyebabkan cacat fungsional, stress emosional dan dapat menyebabkan cacat yang permanen serta kematian. Selain itu juga dari segi ekonomis akan banyak membutuhkan biaya yang disebabkan bertambahnya hari rawat pasien.

Upaya mengantisipasi dan mencegah terjadinya infeksi perlu dilakukan pengkajian dari awal kemudian pengkajian ulang secara berkala mengenai resiko pasien, termasuk resiko potensial yang berhubungan dengan pemberian obat serta mengambil tindakan untuk mengurangi semua resiko yang telah diidentifikasi tersebut (Darmadi, 2008). Upaya nyata yang dapat dilakukan oleh petugas adalah sebelum dan sesudah melakukan tindakan, hendaknya selalu mencuci tangan. Tujuan dari mencuci tangan adalah menurunkan Bioburden (jumlah mikroorganisme) pada tangan dan untuk mencegah penyebarannya ke area yang tidak terkontaminasi. Hasil studi pendahuluan yang dilakukan dengan pendekatan wawancara dan observasi terhadap beberapa pasien yang dirawat di ruang bedah RSUD kabupaten Ende, didapatkan keterangan bahwa beberapa laken yang tampak kusam dan kotor karena belum diganti oleh perawat, dari 5 orang pasien yang ditanyakan tentang prosedur perawatan yang dilakukan perawat seperti memakai sarung tangan (handscoon), 3 orang mengatakan seringkali perawat 
ketika memberikan obat kepada mereka tanpa menggunakan handscoon. Sedangkan 2 orangnya menganggap bahwa penggunaan handscoon tidaklah terlalu penting untuk dilakukan, karena tidak mungkin perawat dapat menjadi sumber dari infeksi. Selain itu juga beberapa keluarga yang diwawancarai tentang perilaku mencuci tangan dari perawat yang mungkin mereka perhatikan, hampir semua anggota keluarga mengatakan bahwa mereka hanya melihat beberapa perawat saja yang mencuci tangan setelah selesai melakukan tindakan keperawatan. penerapan teknik aseptik dalam perawatan pasien di ruang perawatan bedah RSUD Kabupaten Ende. Tujuan penelitian ini adalah untuk mengetahui penerapan teknik aseptik dalam perawatan pasien di ruang perawatan bedah RSUD Kabupaten.

\section{METODE PENELITIAN}

Jenis penelitian yang digunakan dalam penelitian ini adalah penelitian deskriptif. Penelitian deskriptif bertujuan utama untuk memberikan gambaran atau deskripsi tentang suatu keadaan secara objektif (Fiana, 2015). Penelitian ini mendeskripsikan penerapan teknik aseptik dalam perawatan pasien di ruang perawatan bedah RSUD Kaupaten Ende. Desain dalam penelitian ini adalah survey dengan populasi seluruh perawat di ruangan bedah RSUD Kabupaten Ende dan jumlah sampel sebanyak 12 orang. Teknik pengambilan sampel yang diguanakan yakni sampling jenuh dimana jumlah sampel sama dengan jumlah populasi. Kriteria inklusi yakni perawat di ruang bedah, bersedia menjadi responden yang dibuktikan dengan menandatangani inform consent, tidak sedang menjalani cuti dan tugas belajar, pendidikan minimal D3 dan masa kerja minimal 1 satu tahun. Sedangkan instrumen yang digunakan pada proses pengumpulan data adalah lembar observasi. Panduan observasi berisikan panduan tentang teknik aseptik medis dan teknik aseptik bedah yang keseluruhannya berjumlah 10 butir pernyataan. Sedangkan analisa data yang digunakan adalah analisa univariat dengan data disajikan dalam bentuk narasi, tabel distribusi frekuensi dan persentase.

\section{HASIL PENELITIAN}

\section{Karakteristik Responden}

Karakteristik responden yang ikut serta dalam penelitian meliputi: Umur, jenis kelamin, pendidikan, dan pekerjaan.

a. Karakteristik Responden Berdasarkan Jenis Kelamin

Tabel 1 Distribusi Responden Berdasarkan Jenis Kelamin di Ruang Perawatan Bedah RSUD Kabupaten Ende

\begin{tabular}{|c|c|c|}
\hline Jenis Kelamin & Frekuensi (N) & Persent (\%) \\
\hline Laki-laki & 2 & 16.7 \\
\hline Perempuan & 10 & 83.3 \\
\hline Total & 12 & 100.0 \\
\hline
\end{tabular}

Sumber: Data Primer

Tabel 1 di atas menunjukkan bahwa sebagian besar responden mempunyai jenis kelamin perempuan yakni sebanyak 10 orang $(83,3 \%)$ dan sebagian kecilnya mempunyai jenis kelamin laki-laki yakni sebanyak 2 orang $(16,7 \%)$. 
b. Karakteristik Responden Berdasarkan Usia

Tabel 2 Distribusi Responden Berdasarkan Usia di Ruang Perawatan Bedah RSUD Kabupaten Ende

\begin{tabular}{lccc}
\hline & Usia & Frekuensi $(\mathbf{N})$ & Persent $(\boldsymbol{\%})$ \\
\hline$<30$ Tahun & & 4 & 33.3 \\
\hline$>30$ Tahun & & 8 & 66.7 \\
\hline & Total & $\mathbf{1 2}$ & $\mathbf{1 0 0 . 0}$ \\
\hline
\end{tabular}

Sumber: Data Primer

Tabel 2 di atas menunjukkan bahwa sebagian besar responden berusia $\geq 30$ tahun yakni sebanyak 8 orang $(66,7 \%)$ dan sebagian kecilnya berusia $<30$ tahun yakni sebanyak 4 orang $(33,3 \%)$.

c. Karakteristik Responden Berdasarkan Pendidikan

Tabel 3 Distribusi Responden Berdasarkan Pendidikan di Ruang Perawatan Bedah RSUD Kabupaten Ende

\begin{tabular}{|c|c|c|}
\hline Pendidikan & Frekuensi (N) & Persent (\%) \\
\hline S1 Keperawatan & 0 & 0 \\
\hline Ners & 0 & 0 \\
\hline D3 Keperawatan & 12 & 100 \\
\hline Total & 12 & 100.0 \\
\hline
\end{tabular}

Sumber: Data Primer

Tabel 3 diatas menunjukkan bahwa seluruh responden berpendidikan D-III yakni sebanyak 12 orang $(100 \%)$.

d. Karakteristik Responden Berdasarkan Lama Kerja

Tabel 4 Distribusi Responden Berdasarkan Lama Kerja di Ruang Perawatan Bedah RSUD Kabupaten Ende

\begin{tabular}{cccc}
\hline & Lama Kerja & Frekuensi $(\mathbf{N})$ & Persent (\%) \\
\hline$<5$ Tahun & & 4 & 33.3 \\
\hline$>5$ Tahun & & 8 & 66.7 \\
\hline & Total & $\mathbf{1 2}$ & $\mathbf{1 0 0 . 0}$ \\
\hline
\end{tabular}

Sumber: Data Primer

Tabel 4 diatas menunjukkan bahwa sebagian besar responden dengan lama bekerja $>5$ tahun yakni sebanyak 8 orang $(66,7 \%)$ dan sebagian kecilnya dengan lama bekerja $\leq 5$ tahun yakni 4 orang $(33,3 \%)$.

\section{Variabel Responden}

Variabel responden yang ikut serta dalam penelitian meliputi penerapan teknik aseptik medis penerapan teknik aseptik bedah dan penerapan teknik aseptik dalam perawatan pasien di ruang perawatan bedah RSUD Kabupaten Ende

a. Penerapan Teknik Aseptik Medis

Tabel 5 Distribusi Responden Berdasarkan Penerapan Teknik Aseptik Medis di Ruang Perawatan Bedah RSUD Kabupaten Ende

\begin{tabular}{lccc}
\hline & Kategori & Frekuensi $(\mathbf{N})$ & Persent $(\boldsymbol{\%})$ \\
\hline Baik & & 3 & 25.0 \\
\hline Cukup & & 9 & 75.0 \\
\hline Kurang & & 0 & 0 \\
\hline & Total & $\mathbf{1 2}$ & $\mathbf{1 0 0 . 0}$ \\
\hline
\end{tabular}

\section{Sumber: Data Primer}

Tabel 5 diatas menunjukkan bahwa sebagian besar responden menerapkan teknik aseptik medis yang cukup dalam perawatan pasien yakni sebanyak 9 orang $(75,0 \%)$, penerapan yang baik 3 orang $(25,0 \%)$ dan tidak ada yang menerapkan teknik aseptik medis dengan kategori kurang. 
b. Penerapan Teknik Aseptik Bedah

Tabel 6 Distribusi Responden Berdasarkan Penerapan Teknik Aseptik Bedah di Ruang Perawatan Bedah RSUD Kabupaten Ende

\begin{tabular}{lccc}
\hline & Kategori & Frekuensi (N) & Persent (\%) \\
\hline Baik & & 7 & 58.3 \\
\hline Cukup & 5 & 41.7 \\
\hline Kurang & & 0 & 0 \\
\hline & Total & $\mathbf{1 2}$ & $\mathbf{1 0 0 . 0}$
\end{tabular}

Sumber: Data Primer

Tabel 6 diatas menunjukkan bahwa sebagian besar responden menerapkan teknik aseptik bedah yang baik dalam perawatan pasien yakni sebanyak 7 orang $(58,3 \%)$, penerapan yang baik sebanyak 5 orang $(41,7 \%)$ dan tidak ada dengan penerapan teknik aseptik bedah yang

c. Penerapan Teknik Aseptik Dalam Perawatan Pasien di Ruang Perawatan Bedah RSUD Ende

Tabel 7 Distribusi Responden Berdasarkan Penerapan Teknik Aseptik Bedah di Ruang Perawatan Bedah RSUD Kabupaten Ende

\begin{tabular}{lccc} 
& Kategori & Frekuensi (N) & Persent (\%) \\
\hline Baik & 7 & 58.3 \\
\hline Cukup & 5 & 41.7 \\
\hline Kurang & & 0 & 0 \\
\hline & Total & $\mathbf{1 2}$ & $\mathbf{1 0 0 . 0}$ \\
\hline
\end{tabular}

Sumber: Data Primer

Tabel 7 diatas menunjukkan bahwa sebagian besar responden menerapkan teknik aseptik yang baik dalam perawatan pasien yakni sebanyak 7 orang $(58,3 \%)$, penerapan yang cukup sebanyak 5 orang $(41,7 \%)$ dan tidak ada dengan penerapan teknik bedah yang kurang.

\section{PEMBAHASAN}

Aseptik berarti tidak adanya pathogen pada penyakit. Menurut Crow dalam Wina Jivika P (2007) teknik aseptik adalah usaha mempertahankan klien sedapat mungkin bebas dari mikro organisme. Sedangkan menurut Hinchliff (dalam Dwi Handayani, 2003, dalam Setianto, 2015), teknik aseptik adalah metode penjagaan yang digunakan dalam setiap tindakan yang membawa resiko masuknya mikroorganisme ke dalam tubuh pasien.

\section{Penerapan Teknik Aseptik Medis}

Berdasarkan hasil penelitian diperoleh hasil sebagai berikut hasil penelitian dengan tujuan mengidentifikasi penerapan teknik aseptik medis dalam perawatan pasien di ruang perawatan bedah di RSUD Kabupaten Ende, diperoleh hasil bahwa sebagian besar responden cukup dalam menerapkan teknik aseptik medis yakni sebanyak 9 orang $(75,0 \%)$, dengan penerapan yang baik sebanyak 3 orang $(25,0 \%)$ dan tidak ada perawat yang menerapkan teknik aseptik medis dengan kategori kurang. Sebagian besar perawat dengan penerapan yang cukup, meskipun seluruhnya (100\%) perawat sudah membuang kasa/sampah yang berada dalam ruangan perawatan, mencuci tangan sebelum dan sesudah melakukan perawatan kepada pasien/klien, tetapi semua responden tidak pernah membersihkan lantai ruangan perawatan dan hanya sedikit saja yang membersihkan dan menggantikan linen pasien. Berdasarkan Standar Operasional Prosedur (SOP) RSUD Kabupaten Ende, penerapan aseptik medis 
yang baik dan benar adalah; perawat ruangan membersihkan dan menggantikan linen pasien, membersihkan lantai ruangan perawatan, membuang kasa atau sampah yang berada dalam ruangan perawatan, mencuci tangan sebelum dan sesudah melakukan perawatan serta memilah sampah medis dan sampah non medis. Penerapan dengan kategori cukup ini salah satunya disebabkan kurangnya pengalaman atau keterampilan sebagai seorang perawat profesional, dimana ada sebanyak 4 orang $(33,3 \%)$ lama bekerja $\leq 5$ tahun. Selain itu juga mungkin karena perawat ruangan merasa bahwa membersihkan lantai ruangan merupakan tugas dari cleaning service, sehingga mereka tidak perlu melakukan hal tersebut. Menurut Nurachmah (2012), salah satu yang harus dicapai oleh perawat profesional adalah memelihara lingkungan fisik dan psichososial untuk meningkatkan keamanan, kenyamanan dan kesehatan yang optimal. Pernyataan ini menegaskan bahwa bahwa seorang perawat harus memperhatikan kenyamanan dari pasien, tanpa harus menunggu dari bagian lain (cleaning service) untuk melakukan hal tersebut. Untuk mengatasi penerapan aseptik medis yang cukup dari perawat ini, diharapkan pihak Rumah Sakit Umum Daerah Ende selalu memberikan pelatihanpelatihan kepada para perawat mengenai keperawatan yang profesional, sehingga perawat mampu meningkatkan kinerja yang akhirnya akan bermuara pada keamanan dan kenyamanan yang dirasakan oleh pengguna jasa Rumah Sakit, khususnya pasien di Ruangan Perawatan Bedah.

\section{Penerapan Teknis Aseptik Bedah}

Hasil penelitian dengan tujuan penerapan teknik aseptik bedah dalam perawatan pasien di ruang perawatan bedah RSUD Kabupaten Ende, diperoleh hasil bahwa sebagian besar perawat menerapkan teknik aseptik bedah dengan kategori baik dalam perawatan pasien yakni sebanyak 7 orang $(58,3 \%)$, penerapan yang cukup sebanyak 5 orang $(41,7 \%)$ dan tidak ada dengan penerapan teknik aseptik bedah yang kurang. Berdasarkan Standar Operasional Prosedur (SOP) RSUD Kabupaten Ende, penerapan aseptik bedah yang baik dan benar adalah; perawat menata area steril, membuka bungkusan steril, menambahkan alat-alat ke dalam area steril, menambahkan cairan ke dalam area steril dan menggunakan sarung tangan steril. Sebagian besar perawat dengan penerapan yang baik, hal ini terlihat dari seluruh responden (100\%) selalu membuka bungkusan peralatan yang steril, menambahkan alatalat ke dalam area steril dan selalu menggunakan sarung tangan steril, serta sebagian responden sudah menata area yang steril sbelum dilakukannya tindakan dan menambahkan cairan ke dalam area steril.

Penerapan yang baik ini mungkin dikarenakan sebagian besar responden dengan lama kerja $>5$ tahun, sehingga mereka sudah mengetahui SOP (Standar Operasional Prosedur) yang harus dilakukan. Hal lain yang menyebabkan penerapan teknik aseptik bedah yang baik adalah perawat mengerti bahwa jika salah dalam melakukan tindakan perawatan, maka akan berakibat fatal bagi pasien. Hal ini sesuai dengan pendapat (Schaffer dkk, 2004 dalam Setianto, 2015) yang menyatakan bahwa perawat yang bekerja dengan lingkungan yang steril atau dengan peralatan yang seteril harus mengerti bahwa kegagalan sekecil apapun dalam teknik ini mengakibatkan kontaminasi yang akan membuat pasien beresiko terkena infeksi luka operasi yang dapat menghambat proses penyembuhan sehingga keterampilan dan kemampuan dari perawat ruangan harus tetap ditingkatkan dengan mungkin 
mengikuti pelatihan-pelatihan yang diberikan oleh tenaga yang ahli dan terampil.

\section{Penerapan Teknik Aseptik Dalam Perawatan}

Penerapan teknik aseptik yang baik dalam perawatan pasien yakni sebanyak 7 orang $(58,3 \%)$, penerapan yang cukup sebanyak 5 orang $(41,7 \%)$ dan tidak ada dengan penerapan teknik bedah yang kurang. Praktik kepatuhan perawat ruang perawatan dalam melaksanakan teknik aseptik pada umumnya sudah cukup baik. Meskipun masih terdapat beberapa perawat yang masih kurang tepat dalam pemilihan penggunaan APD sehingga masih berisiko membuat pasien terpapar HAIs. Penggunaan APD yang paling banyak ditemukan kekeliruanya adalah penggunaan sarung tangan. Kesalahan perawa dalam menggunakan sarung tangan antara lain, menggunakan sarung tangan bersih untuk tindakan keperawatan yang membutuhkan sarung tangan steril, dan juga menggunakan sarung tangan untuk tindakan yang tidak membutuhkan sarung tangan karena tidak berisiko untuk terkena darah dan cairan tubuh (WHO, 2015).

Tindakan tersebut misalnya adalah membagikan obat oral, melakukan pemeriksaan tanda-tanda vital, dan juga memberikan injeksi melalui selang infus (intravena). Apalagi perawat hanya menggunakan satu pasang sarung tangan untuk banyak pasien tanpa melakukan cuci tangan atau disinfeksi setelahnya. Urban (2016) menjelaskan bahwa hal tersebut jika berlangsung terus menerus dapat menyebabkan kontaminasi silang. Rumah sakit mempunyai buku SOP tersendiri yang berisikan antara lain adalah standar alat dan langkah-langkah tindakan tindakan keperawatan. Dari hasil observasi, didapatkan lima orang perawat melakukan ganti balut luka bersih menggunakan sarung tangan bersih dan empat orang perawat menggunakan sarung tangan lebih dari sepasang saat melakukan ganti balut. Dua orang perawat juga masih menggunakan sarung tangan bersih untuk tindakan suction, endotracheal tube (ET), dan trakeostomi, dan seorang perawat menggunakan sarung tangan bersih untuk pemasangan kateter urin. Hal tersebut tidak sesuai dengan SOP rumah sakit yang mencantumkan standar alat berupa sarung tangan steril untuk tindakan-tindakan tersebut. (Kemenkes RI, 2017; WHO, 2016).

\section{KESIMPULAN}

Berdasarkan hasil penelitian mengenai penerapan teknik aseptik dalam perawatan pasien di ruang perawatan bedah RSUD kabupaten Ende, maka dapat ditarik kesimpulan bahwan sebagian besar perawat menerapkan teknik aseptik medis dengan kategori cukup dalam perawatan pasien dan sebagian besar perawat menerapkan teknik aseptik bedah dengan kategori baik dalam perawatan pasien. Sedangkan secara umum dapat disimpulkan bahwa sebagian besar perawat menerapkan teknik aseptik dengan kategori baik dalam perawatan pasien yakni sebanyak 7 orang $(58,3 \%)$, penerapan dengan kategori cukup sebanyak 5 orang $(41,7 \%)$ dan tidak ada penerapan teknik aseptik dengan kategori kurang. 


\section{DAFTAR PUSTAKA}

Centre for Disease Control and Prevention. (2015). Personal protective equipment. Diperoleh dari https://www.cdc.gov/niosh/topics/emres/ppe.html

Darmadi, 2008, Infeksi Nosokomial : Problematika dan Pengendaliannya, Jakarta, Penerbit Salemba Medika

Setianto, 2015, Konsep Dasar Teknik Aseptik, Internet, Tersedia Dalam : http://www. herusetianto. Com /2015/02/konsep-dasar-teknik-aseptik.html, diakses tanggal 28 Mei 2016.

Febriani, 2015, Konsep Aseptik, Internet, Tersedia Dalam : http://filekeperawatan. blogspot. co.id /2015/ 04/Konsep-Aseptik.html, diakses tanggal 26 Mei 2016

Fiana, 2015, Pengertian dan Jenis-Jenis Penelitian Deskriptif, Internet, Tersedia Dalam : http://artikelilmiahlengkap.blogspot.co.id, diakses tanggal 30 Mei 2016.

Hinchliff, 1999, Kamus Keperawatan, Edisi 17, Jakarta, EGC.

Jeyamohan, D. (2010). Angka prevalensi infeksi nosokomial pada pasien luka operasi pasca bedah di Bagian Bedah di Rumah Sakit Umum Pusat Haji Adam Malik, Medan dari Bulan April sampai

September 2010. Universitas Sumatera Utara. Diperoleh dari http://repository.usu.ac.id/handle/123456789/21521

Kasmad, 2007, Hubungan Antara Kualitas Perawatan Kateter Dengan Kejadian Infeksi Nosokomial Saluran Kemih, E-Journal, Semarang, Universitas Diponegoro.Kayser, 2005, Color atlas of Medical Microbiology, Stuttgart, New York.

Rutala, 2003, Guideline for Disinfection and Sterilization in Healtcare Facilities, Internet, Tersedia Dalam : http://www.aamu.edu csd/docs/universal precautions. pdf, diakses tanggal $30 \mathrm{Mei}$ 2016.

Verawati, 2015, Asuhan Keperawatan pada Anak Demam Kejang, Internet, Tersedia Dalam : https://indahverawati.wordpress.com/author/, diakses tanggal 26 Maret 2016.

Wardhono, 1998, Menuju Keperawatan Profesional, Semarang, Akper Depkes WHO, 2007, Pencegahan dan Pengendalian Infeksi Saluran Pernapasan Akut (ISPA) yang Cenderung Menjadi Epidemi dan Pademi di Fasilitas Pelayanan Kesehatan, Trust Indonesia.

World Health Organization. (2016). Guidelines on core components of infection prevention and control programmes at the national and acute health care facility level. Geneva. 